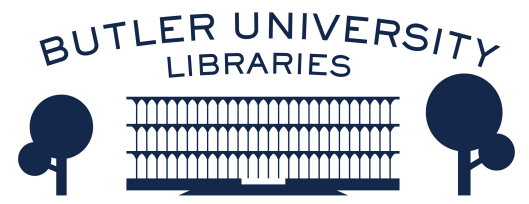

Journal of Hindu-Christian Studies

Volume 32 Discussion of Nathaniel Roberts, To

Be Cared For: The Power of Conversion and

Foreignness of Belonging to An Indian Slum.

Article 12

2019

\title{
Book Review: Hagiography and Religious Truth: Case Studies in the Abrahamic and Dharmic Traditions
}

Jon Paul Sydnor

Emmanuel College (Boston)

Follow this and additional works at: https://digitalcommons.butler.edu/jhcs

\section{Recommended Citation}

Sydnor, Jon Paul (2019) "Book Review: Hagiography and Religious Truth: Case Studies in the Abrahamic and Dharmic Traditions," Journal of Hindu-Christian Studies: Vol. 32, Article 12.

Available at: https://doi.org/10.7825/2164-6279.1738

The Journal of Hindu-Christian Studies is a publication of the Society for Hindu-Christian Studies. The digital version is made available by Digital Commons @ Butler University. For questions about the Journal or the Society, please contact cbauman@butler.edu. For more information about Digital Commons @ Butler University, please contact digitalscholarship@butler.edu. 
expository footnotes, as well as in-text explanations of technical or region-specific terms that may be unfamiliar to a broader audience. Possessed of a free-flowing narrative style, the work defies the structure of conventional academic writing. It unfolds instead with a focus on gradual character development and plot lines that showcase Bloomer's training as both an ethnographer and a literary writer. While this style makes it challenging at times to identify the structural direction of each consecutive chapter, it imbues the work with an enthralling character. Bloomer's rich descriptions of everyday moments and defining events absorb the reader with the interest of a novel while remaining deftly tied to her analytical framework.

This brilliant study is a substantive contribution to the growing body of ethnographic literature centered on women as living religious authorities, wielding their power at the margins of established religious orthodoxies. Moreover, this study is of critical importance to discussions of methodology among ethnographers of religion. Bloomer highlights the complexities of conducting an ethnography "as a friendly researcher," "a potential skeptic," and a "tall, unmarried farangi" (206) with the resources to travel internationally and conduct research. Effectively voicing the "ambiguities of being a witness" (55), she charts a path for articulating, in a "relationship of reciprocity" (206), the experiences of women and men whose lived realities radically differ. A methodical reflexivity is also built into the study's structure. Drawing from the Tamil Cankam poetic conventions of the akam ("inner") and puram ("outer") modes of expression for love and politics or war respectively, Bloomer highlights the inherently subjective, dialogic nature of describing religious experiences. Her subheading system draws from the multivocal akam poetic mode, an approach that emphasizes the ethnographer's subjectivity as well. Moreover, Bloomer's candor in relation to her research process conveys the fundamental challenges of conducting ethnographies of religion in the first place, summarized aptly in a question that arose during one Marian possession event: "How do you interview the Mother of God?"

Claire C. Robison

Bowdoin College

\section{Hagiography and Religious Truth: Case Studies in the Abrahamic and Dharmic Traditions. Edited by Rico G. Monge, Kerry P. C. San Chirico, and Rachel J. Smith. New York: Bloomsbury, 2016, Xv +265 pages.}

JEFFREY J. KRIPAL of Rice University sets the stage for Hagiography and Religious Truth. In his powerful forward, he reminds us that religious phenomena are, for lack of a better word, real-we experience them, they transform us, and they defy all reductionist interpretation. They are what they are, not less (xiii-xv). Therefore, conclude our editors, the best strategy to understand religious phenomena (saints, in this instance) is not to explain them away through materialist, psychological, or sociological strategies. The best way to understand them is through comparison, placing saint into relationship with saint, across times and traditions, in order to elicit their more. Such comparison 
strips the known of its obviousness, interrogates the familiar, and reveals overlooked aspects of the religious heroes whom we revere. Drs. Rico G. Monge, Kerry P. C. San Chirico, and Rachel J. Smith have achieved this hagiographic comparison in their new volume, Hagiography and Religious Truth, which fulfills its great promise.

But Hagiography and Religious Truth is more than a comparative endeavor. Part I, consisting of three essays, introduces current hagiographical theory: What is hagiography, and what does it do? How should we read it? What if the story never happened? Through these questions, the authors elicit contemporary debates and explore a range of interdisciplinary answers. Part II provides case studies in the dharmic traditions of Hinduism and Buddhism. Chapters in this section establish how hagiographic traditions can diverge, detail the evolving relationship between a saint and the sacred space celebrating him, and describe the ascent with modification of a hagiography from India to Tibet. Part III provides case studies in Abrahamic hagiography, including two essays on the various political uses of hagiography, an essay on hagiography and liturgy, and an essay on the interiorization of saintly values by saints' devotees. Finally, Part IV is explicitly comparative. Essays there illustrate the power of hagiography to provide theological legitimation, the liminal saints of HinduChristian Khrist Bhaktas in Varanasi, and the religious traditions' insistence that no saint can be understood through reductionist approaches. The volume concludes with a fine response by Francis X. Clooney.

Due to the space limitations of this review, I will here address in-depth only four chapters. For comprehensiveness, I will choose one essay from each section. My choice is in no way an evaluation of any chapter.
In Part I, Rico G. Monge discusses the fraught relationship between academic biography and hagiography in "Saints, Truth, and the 'Use and Abuse' of Hagiography." America's positivist culture, which demands that truth be publicly verifiable, prefers biography as a collation of facts to hagiography as a manifestation of transformative power (2). But in our morally challenged times, do we need more data or more saintliness (9)? The "academic" denigration of hagiography as embellished, faithless biography may miss an opportunity for subjective and collective transformation, the opportunity we most need (12). In making this claim, Monge is not advocating literalist fundamentalism or nihilist aestheticism; he does not deny the importance of facts or science. He is instead suggesting that we allow hagiography to do what it was intended to do (18). Those who authored the lives of saints were not trying to get tenure in academic institutions; they were trying to inspire, and their works should be judged by that criterion.

In Part II, Mark McLaughlin discusses the saint as the nondual (advaita) form of the formless in "Turning Tomb to Temple: Hagiography, Sacred space, and Ritual Activity in a Thirteenth-century Hindu Shrine." He probes the fascinating case of Jñāneśvar, a medieval Hindu saint from Maharashtra. Jñāneśvar dug a meditation room beneath a temple to Siva, had his followers block in the door, and went into samjīvan samādhi, living absorption into Brahman, in which the meditator is freed from all the restraints of embodied existence (70). Graciously, Jñāneśvar left behind his body and its store of karmic merit (73). Today, 700 years later, devotees come to his tomb to take darśan, to see and be seen by the saint, and receive his infinite merit. They do so through his samādhi marker, a bronze bust. Through 
the intimacy of vision, devotees interact with Jñāneśvar as form and formless, as person and Brahman, as here and everywhere. Paradoxically, they see nonduality and are seen by nonduality. Through this ritual activity, they are invited into Brahman, the true form of all things (87-88).

In Part III, Vernon J. Schubel highlights Islamic devotion to saints in "The Transmission of Virtue in the Hagiography of Haci Bektas Veli: The Narrative of Guvenc Abdal." Academic introductions to Islam tend to focus on the Qur'an, the five pillars, and Salafi legalism, while the media focus on Wahabism, shariah law, and militancy. Overlooked are the intimate interpersonal relationships fostered by Islam, such as love of God, emulation of Muhammad, and devotional allegiance to the evliya-i Allah (Turkish), the "Friends of God," Sufi "saints." Muslims, especially the Alevi mystics that Schubel studies, try to transform their essential personality through relationship with these paradigmatic human beings, who provide ethical inspiration but also blessing, guidance, and miraculous interventions (112-114). So powerful is the saints' holiness that devotees' interior journey with them can lead to insan al-kamil, the perfected human being (115). In order to illustrate this practice, the chapter discusses Haci Bektas Veli, the most important mystic to Alevi Muslims, and his effect on followers (117-122).

In Part IV, Kerry P.C. San Chirico describes the inherently comparative practice of one Hindu-Christian sect in "Holy Negotiations in a Hindu Heartland: Abundant People and Spaces Among the Khrist Bhaktas of Banaras." San Chirico writes about a liminal case, lowcaste Christ-worshipers who are both Hindu and Christian, hence neither Hindu nor Christian. Jesus is their chosen God, whom they worship much as Hindus worship their
Kṛșna. Khrist Bhaktas refuse baptism, yet receive the gifts of the Spirit, especially that of healing. Uniquely, San Chirico's essay is not so much about hagiography; it is hagiography, and the saints are the Khrist Bhaktas themselves. They are abundant persons, "a people connected to God in a special way," the egalitarian oppressed, blessed by their condition with sturdy faith (188). They do not believe in Jesus; they know Jesus, as the nursling knows her mother, and they share that knowledge with the world (192). They are thus saints (holy persons, in English) and sants (persons abundant in being, in Hindi), both of this world and beyond it, transformative manifestations of abundance. As such, they are a proper object of study for any hagiographer, even if he is also an academic (197-198).

In this rewarding volume, I will admit that I found one discussion missing. In a volume on hagiography, I would have appreciated more discussion of what constitutes sainthood. San Chirico briefly touches upon it (186), as does Smith (26-27), but further development would have been helpful. When I think of a saint, progressive Protestant that I am, I tend to automatically think of an especially kind, gentle, or peaceful person: Mother Teresa, Gandhi, the Dalai Lama, or all of my Sunday school teachers growing up. My saints are domesticated, perhaps even cuddly. But religious traditions often ascribe sainthood (insofar as the concept translates) to persons who are religiously obsessive, self-destructive, militant, or overweening. In a tribal framework, within which many religious operate, their saint may be our villain, and vice versa. The saints described in Hagiography and Religious Truth tend to be what open-minded Westerners think of as saints; they're generally not threatening or dangerous. A deeper consideration of the 
multivalence of saintliness-and its moral ambiguity-may have helped inform the various, otherwise excellent, discussions.

That being said, this volume fills a yawning gap in interreligious study, and it is very well executed. The structure is logical, the writing clear, and the subject compelling. I found it academically and spiritually stimulating and commend it to anyone who seeks to learn more about those extraordinarily abundant human beings whom we call saints.

Jon Paul Sydnor

Emmanuel College (Boston)

\section{Imaginations of Death and the Beyond in India and Europe. Edited by Günter Blamberger and Sudhir Kakar. Singapore: Springer Nature, 2018, ix + 202 pages.}

THIS volume brings together twelve essays from a 2014 conference, "Figurations of Afterlife/Afterdeath," held in New Delhi and funded by the German Federal Ministry of Education and Research. As noted in the volume's brief, unattributed introduction, the central concern of the conference was to ask "How can literature and the arts in general help us cope with [the] knowledge of death?" (vii). Underlying this question is the problematic nature of the knowledge of death itself; indeed, as the author of the introduction notes, death, which characteristically is laden with uncertainty, carries us "beyond all rational analysis" (vii).

Yet, whereas an earlier age looked to the world of religion to approach the unknowable, as editor and contributor Günter Blamberger observes, "religion has lost its influence as a common master discourse providing answers to fundamental problems..." (21). Blamberger suggests that in its place, in the modern world, "what really matters is that almost everybody pays attention to the artifacts of literature, of the arts, or of mass media to study their depiction and their reading of traditionally religious questions of disease and death, good and bad, justice and injustice, love and grief, community and solitude" (21). This notion of the arts as a repository of what was once located in traditional religious discourse recurs throughout the volume, as individual essays delve broadly into modern film, literature, and the created worlds of social and political discourse. However, alongside this core, traditional religious notions are cited over and again; in particular, mythologies of the afterlife and deathways are treated in several essays, and are appealed to in others as points of contrast.

The twelve essays are grouped under four headings: Initial Questions (consisting of two essays by the editors Kakar and Blamberger that loosely frame the collection as a whole); Questions of Immortality; Questions of Visuality; and Questions of Transition. Interspersed in each section are essays that discuss European notions of death and the afterlife (the majority of the essays) with others that consider Indic materials. These two nodes (European and Indic) are set off by a brief introductory section that juxtaposes a Grimm story of an encounter with Godfather Death with the famed Kathopanishad (ca. 5th c. BCE) tale of the meeting between the brahmin boy Nachiketas and the God of Death (Yama). 